\title{
Effect of milking time, lactation stage and udder traits on milk yield of Red Sokoto and Boer goats in semi-arid Kano, Nigeria
}

${ }^{* 1}$ Muhammad, H. A., ${ }^{2}$ Garba, Y., ${ }^{3}$ Ogah, D. M. and ${ }^{1}$ Inusa, S. K.

${ }^{\prime}$ Department of Animal Science, Faculty of Agriculture, Bayero University, Kano, P.M.B 3011 Kano, Nigeria

${ }^{2}$ Centre for Dryland Agriculture, Bayero University, Kano,

P.M.B 3011 Kano, Nigeria

${ }^{3}$ Department of Animal Science, Faculty of Agriculture,

Nasarawa State University,

Keffi, Shabu-Lafia Campus, P.M.B. 135, Lafia, Nigeria

*Corresponding author: hamuhammad.asc@buk.edu.ng;

Abstract $+2348066241225$

The aim of the study was to evaluate the effect of milking time, lactation stage and udder traits on milkyield of Red Sokoto and Boer goats at the Teaching and Research farm of Centre for Dry-land Agriculture, Bayero University Kano, Nigeria. The first evaluation of milk yield was done at early stage of lactation starting after day seven of kidding to exclude colostrum. Daily collection of milk samples followed in the morning and evening until 10 weeks of lactation. The weeks were divided into 3 stages of lactation as early, mid and late lactation stages. Milk samples were measured using a $100 \mathrm{~mL}$ measuring cylinder and later converted into grammes. The external udder measurements were taken in $\mathrm{cm}$ after seven days post kidding and fortnightly for the period of lactation. The result obtained shows significant difference $(p<0.05)$ in the total morning milk yield between the goats. The total morning milk yield was higher $(2642.00 \pm 3.18 \mathrm{~g})$ in the Boer goats than in the Red Sokoto $(2371.50 \pm 3.18$ g). However, the average daily milk yield, total milk yield and total evening milk yield were not significantly $(p>0.05)$ affected by the goat breeds. Mean milk yield was significantly $(p<0.05)$ influenced by stage of lactation and time of milking. The milk yield was significantly higher $(98.91 \mathrm{~g})$ in the late lactation while the least was obtained in the mid stage of lactation (65.44 g). However, the morning milk yield was significantly higher than the evening milkyield. A significant interaction effect $(p<0.05)$ of lactation stage and milking time was similarly observed. The results indicated that breed significantly $(p<0.05)$ influenced most of the udder traits except $U C$, $U W$ and TFD. Significantly $(p<0.05)$ higher values of UL, UW, TC, RTL, LTL, CH and TFD were recorded in the Red Sokoto. Furthermore, the Boer goat breed had significantly higher values of UC and DBT.

Keywords: Red Sokoto goat, Boer, stage of lactation, udder traits.

Effet de la durée de traite, de la phase de lactation et des traits de pis sur le (2) rendement en lait de Red Sokoto et de Boer Chèvres à Semi-aride, Nigéria

\section{Résumé}

Le but de l'étude était d'évaluer l'effet de la traite de traite, de la phase de lactation et des traits de la piste sur le rendement du lait de Red Sokoto et des chèvres de Boer à la ferme du Centre d'agriculture à sec, de l'Université Bayero Kano, du Nigéria. La première évaluation du rendement en lait a été effectuée à un stade précoce de l'allaitement à partir de sept jours de blague pour exclure le colostrum. La collecte quotidienne d'échantillons de lait a suivi le matin et le soir jusqu'à 10 semaines de lactation. Les semaines ont été divisées en 3 étapes de 
la lactation comme des étapes de début et de lactation tardive. Les échantillons de lait ont été mesurés à l'aide d'un cylindre de mesure de $100 \mathrm{ml}$ et convertis ultérieurement en grammes. Les mensurations externes de la mamelle ont été prises en cm après sept jours après la mise bas et tous les quinze jours pendant la période de lactation. Le résultat obtenu présente une différence significative $(p<0,05)$ dans le rendement le lait total du matin entre les chèvres. Le rendement au lait total du matin était plus élevé $(2642,00 \pm 3,18 \mathrm{~g})$ dans les chèvres Boer que dans le Sokoto rouge (2371.50 $\pm 3,18 \mathrm{~g})$. Cependant, le rendement quotidien moyen quotidien, le rendement total du lait et le rendement au lait total de la soirée n'étaient pas significativement $(p>0,05)$ affectés par les races de chèvre. Le rendement en lait moyen était significativement $(p<0,05)$ influencé par la phase de lactation et du temps de traite. Le rendement en lait était significativement plus élevé $(98,91 \mathrm{~g})$ à la fin de la lactation, tandis que le moindre a été obtenu au stade moyen de la lactation $(65,44 \mathrm{~g})$. De plus, le rendement au lait du matin était nettement supérieur au rendement le lait du soir. Un effet d'interaction significatif $(P<0,05)$ de stade de lactation et de délai de traite a été observé de la même manière. Les résultats ont indiqué que la race de manière significative $(p<0,05)$ a influencé la plupart des traits de pis de la piste, à l'exception des UC, UW et TFD. De manière significative $(p<0,05)$ des valeurs plus élevées d'UL, UW, TC, RTL, LTL, CH et TFD ont été enregistrées dans le Red Sokoto. De plus, la race de chèvre Boer avait des valeurs significativement plus élevées de UC et DBT.

Mots-clés: Chèvre rouge Sokoto, Boer, Etape de lactation, Traits de pis.

\section{Introduction}

The goat (Capra hircus) represents one of the most important livestock species found in many parts of the world. Goats were the first food animals to be domesticated by humans about 10,000 years ago and developed around the world into hundreds of different breeds (Hatziminaoglou and Boyazoglu, 2004; Park and Haenlein, 2006). The number of goats has increased globally to an estimated population of about $1,184,298,887$ billion, out of which $79,382,178$ million are reared in Nigeria (FAOSTAT, 2018). The largest numbers of goats are found in Asia, followed by Africa, representing about 59.7 and $33.8 \%$, adding up to $93.5 \%$ of the total world population. The lowest population of goats is found in Oceania, which account for $0.1 \%$ of the total global population (FAOSTAT, 2008). China, India, Pakistan and Bangladesh have the highest populations of about $60 \%$ of the world's goat population. The highest income from goat production is derived from meat sales, although there has been spontaneous rise in goat milk production and consumption ( $\mathrm{Lu}$ and Miller, 2019). Though, the worldwide dairy goat population was estimated to be 218 million in 2017 (FAOSTAT, 2019), globally, the dairy goat numbers continue to rise with dramatic increase in the 1990s. The Red Sokoto is the most important breed that is widely distributed in Northern Nigeria and is estimated to represent half of the total goat population in the country (Makun et al., 2005). The main geographical area of the Red Sokoto or Maradi goat covers the Department of Maradi, which is located in the Sudano-Sahelian zone. The Red Sokoto or Maradi goat is found in the South-West of Zinder in Niger Republic and NorthWestern Nigeria where it is named the "Red Sokoto goat" (AU-IBAR, 2020). It inhabits the sub-humid and semi-arid regions of the country with a relatively small body size that is fairly slender. The Red Sokoto goat is usually deep red and occasionally lighter in colour. Both sexes are horned with short ears having medium width and usually carried horizontally. Its withers are not prominent and it possesses well developed 


\section{Muhammad, Garba, Ogah and Inusa}

udder (Otoikhian and Orheruata, 2010). The improved Boer breed was developed in semi-arid South Africa after selection for enhanced weight gain from the unimproved goat populations in 1970 under the South African Mutton and Goat Performance and Progeny Testing Scheme (Casey and Van Niekerk, 1988; Campbell, 2003). Boer goat (Capra aegagrus hircus) is considered to be one of the most desirable goat breeds for meat production. It has gained worldwide recognition for excellent body conformation and good carcass quality. It was demonstrated that Boer goats can improve the productive performance of many breeds through cross breeding with a significant impact on global meat goat industry (Lu, 2001). Boer goats are generally white colored with brown or red heads. Mature weights of Boer bucks and does are 90-130 $\mathrm{kg}$ and 80-100 kg respectively. Milk production of Boer goats is generally considered adequate for rearing multiple kids (Campbell, 1984). In developing countries, research and development investments to improve the relatively low level of goat productivity do not match their potential, as a result of which many goat breeds are not genetically exploited (Abdel Aziz, 2010). Attempts on genetic improvement programmes for indigenous goats in developing countries have lagged behind despite their large population. Ibrahim (2000) reported that the indigenous goats in the tropics are well known for their tolerance to the environment. He also added that goats generally exhibit low productive performance; this may be due to many factors such as poor nutrition, prevalence of diseases and inadequate breeding strategies. Thus, there is need for intensification production; intensification of livestock production involves keeping small flocks of highly productive animals. In this regard, the use of improved exotic breeds has been advocated for long. There has been a recent introduction of highly productive breeds of Boer goat into Nigeria. The milk yield of the Red Sokoto does have been reported to be in the range of 300-660 g/day (Akpa et al., 2002) on agropastoralist farms. Thus, the above trait has potential to be improved since goats possess peculiar qualities that are not common to other ruminants (Silanikove, 2000). These qualities include selective grazing and browsing, better digestibility of roughage, higher milk production per unit weight and high fecundity (Goonewardene et al. 1999; Devendra, 2000; Negesse et al. 2001). The information on breed difference, nutrition and lactation stage and their interaction with other factors are valuable for making management decisions in order to get the best milk composition (Assan, 2014). Malau-Aduli et al. (2001) reported that goat milk yield and composition are affected by breed, age, stage of lactation, season and plane of nutrition. Goat milk and its products are very essential in everyday nutrition. Goat milk is used to produce butter, kefir, curd, yoghurt, cheese and other products. Goat milk is also effective in treating eczemas, migraine, hay fever and constipation. It contains vitamin A, potassium, calcium and phosphorus making it suitable for persons suffering from cardiovascular diseases. It also contains vitamins $\mathrm{B}_{1}, \mathrm{~B}_{2}$ and $\mathrm{C}$ which increase resistance to various diseases. Goat milk can be consumed by people allergic to cow milk. Proteins contained in milk protect children from diarrhea (Zapasnikienè, 2015). Currently, the composition of goat milk is receiving great attention. Goat milk is mainly made up of water $(87.8 \%)$, while other dry substances constitute the remaining (12.2\%). Therefore, the aim of this study was to evaluate the milk production potential of pure-bred Red Sokoto and Boer goat breeds in semi-arid Kano, Nigeria. 


\section{Materials and methods}

\section{Experimental location}

The study was conducted in the pure breed herd of Red Sokoto and Boer goats of the Centre for Dryland Agriculture Training and Research Farm, Bayero University, Kano located on longitude 1058.771' East and latitude 8025.851 ' North at an altitude of $472 \mathrm{~m}$ above sea level. The two breeds were managed to study the performance of the goats in terms of growth and lactation which will serve as a base line studies upon which improvement through selection and cross breeding could be made. The average monthly minimum and maximum temperature of the study locations were $18.6^{\circ} \mathrm{C}$ and $34^{\circ} \mathrm{C}$ respectively. The total annual rainfall and average relative humidity were $1396 \mathrm{~mm}$ and $45.4 \%$ respectively (Nigerian Meteorological Agency; NiMet, 2014).

\section{Source of experimental animals}

Ten pure South African Boer goats were purchased from Majestic Dairy Farm Birnin-Kudu, Jigawa State comprising of eight does and two bucks. The twenty pure Red Maradi goats comprising of seventeen does and three bucks were purchased from the Secondary Center of Caprine Breeding, Maradi, Niger Republic located $1.5 \mathrm{~km}$ east of the city of Maradi in Niger Republic.

\section{Experimental goats and their management}

The goats used were in the age range of 9 to 12 months old. Ages were determined through records and dentition. Pregnancy diagnoses as well as inspection of the general health of the animals were carried out before purchase. Goats were quarantined for two weeks before commencement of the study and another two weeks for adaptation. Goats were kept in pens with half wall for adequate ventilation. The experimental pens were thoroughly cleaned and disinfected before the transfer of the goats and sanitation was carried out on regular basis throughout the study period. They were offered feed and clean drinking water ad libitum.

The goats were treated against endoparasites with Albendazole suspension at $7.5 \mathrm{mg}$ per $\mathrm{kg}$ body weight and Oxytetracycline (a long acting formulation) at $10 \mathrm{mg}$ per $\mathrm{kg}$ body weight. External parasites were also controlled using Pouron ${ }^{\circledR}$ containing Cypermetrine. Sick goats were isolated and treated as appropriate. The goats were raised in a semi-intensive system with concentrates and roughages offered twice a day ( $5 \%$ of body weight). The concentrate mixtures contained $19.14 \%$ crude protein which was fed to the goats in the morning and evening. Feed ingredients used in formulating the diets include cottonseed cake, wheat offal, rice mill waste, poultry litter, cowpea husk, "Kalgo pods" (Piliostigma reticulatum), groundnut hay and salt. The mixture of concentrate and roughage provided was in the ratio of 60:40, respectively. Roughage in the form of groundnut hay was provided to the goats ad libitum. Soybean wastes were also added to the rations of the lactating goats.

\section{Data collection \\ Milk collection procedure Assessment of milk production traits}

The first evaluation of milk yield was done at early stage of lactation starting after day seven of kidding to exclude colostrum. Milk yield was recorded 3 days per week during the first 10 weeks of lactation and average daily yield, weekly yield and total yields were then estimated. Udders were wiped using damp towel with Dettol ${ }^{\circledR}$ as a disinfectant to avoid contamination. The samples were collected in clean bottles, with tight covers to prevent leakage and contamination. Milk samples were measured using a $100 \mathrm{~mL}$ measuring cylinder immediately after collection and later converted into grammes. Milk production traits were measured for each 
lactating doe as average daily milk yield (DMY), total morning milk yield (TMMY), total evening milk yield (TEMY) and total milk yield (TMY). Morning milk yield was measured by isolating kids from their dams at $5.00 \mathrm{pm}$ and then weighed the following morning at $8.00 \mathrm{am}$. They were then allowed to suckle their dams until satisfaction. The increase in kid's weight after each suckling was considered as their milk consumption. The does were hand milked in order to estimate residual milk (stripped milk). The sum of suckled and stripped milk represents the quantity of the morning milk yield (MMY). Alternatively, kids were weighed before suckling as $\mathrm{W}_{1}$ and weighed again after suckling as $\mathrm{W}_{2}$. The difference in weight between $\mathrm{W}_{2}-\mathrm{W}_{1}$ gave the amount of milk consumed per kid as $\mathrm{W}_{3}$. The weights were measured with weighing balance in grammes. Similar procedure was followed in estimating the evening milk production. The sum of morning and evening milk yield represent daily milk yield (DMY). Total milk yield (TMY) was calculated as the sum of milk during suckling period and milking period (Shaat, Mabrouk, Raheem and Hamed, 2009). The study was carried out for a period of 10 weeks. These weeks were divided into 3 stages of lactation viz:

i) Stage 1 (Early lactation): Milk samples taken in the $1^{\text {st }}$ and $2^{\text {nd }}$ week.

ii) Stage 2 (Mid lactation): Milk samples taken in the $5^{\text {th }}$ and $6^{\text {th }}$ week.

iii) Stage 3 (Late lactation): Milk samples taken in the $9^{\text {th }}$ and $10^{\text {th }}$ week.

\section{Measurement of udder traits}

The external udder measurements were taken after seven days and fortnightly for the period of lactation (10 weeks) as described by Papachristoforou and Mavrogenis (1981). All measurements were taken in $\mathrm{cm}$ before milking the does. The animals were adequately restrained in a standing position. The external udder measurements taken include:

i) Udder length (UL), from attachment to middle of udder,

ii) Udder circumference (UC), above teats measured with a flexible tape,

iii) Right and left teat length (TL), from attachment of teat with udder to the end of teats,

iv) Udder width (UW), above teats at rear of udder and

v) Distance between teats (DBT), between two teats attachment with udder.

vi) Cistern height $(\mathrm{CH})$, was taken as the distance from the base of the teat to a point midway before the attachment of the udder to the abdominal wall,

vii) Teat floor distance (TFD), as the distance between the tip of the teat and the ground.

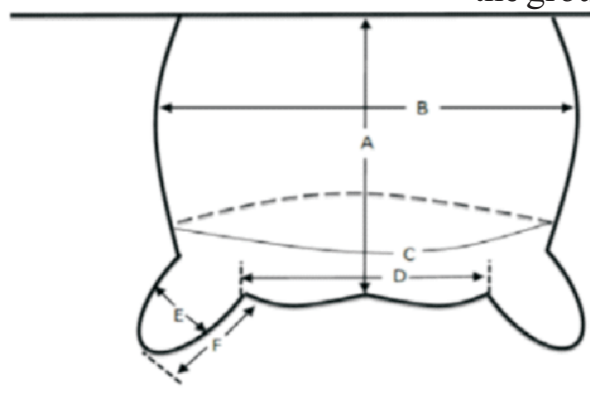

Figure 1. Quantitative Measurements of Udder traits
A. Udder length from attachment to middle of udder.
B. Udder width.
C. Udder circumference above teats.
D. Straight distance between teats.
E. Teat diameter.
F. Teat length 


\section{Experimental design and data analysis}

The experiment was laid in a completely randomized design (CRD) of a $2 \times 3 \times 2$ factorial arrangement. The factors were the goat breeds (Red Sokoto and Boer), stage of lactation (early, mid and late) and time of milking (morning and evening). Data collected were screened for missing values and outliers prior to analysis. All data analyses were executed using Excel and JMP pro 14.0 Statistical Analysis System (SAS, 2018). The data on milk traits were analyzed by least squares techniques using the general linear mixed model procedure of SAS. Breed, stage of lactation and time were considered the fixed effects while, replication as a random effect as presented in the following equation. Significant mean differences were separated at 5\% level of probability using the studentized t-test and Tukey-HSD as the case may be. The model used is as follows:

$\mathrm{Y}_{\mathrm{ikl}}=\mu+\mathrm{B}_{\mathrm{i}}+\mathrm{S}_{\mathrm{k}}+\mathrm{T}_{1}+\mathrm{e}_{\mathrm{iklmnopq}}$

$\mathrm{Y}_{\mathrm{ikl}}=$ response variable

$\mu=$ Overall Mean

$\mathrm{B}_{\mathrm{i}}=$ fixed effect of $\mathrm{i}^{\text {th }}$ breed ( $\mathrm{i}=$ Red Sokoto and Boer)

$\mathrm{S}_{\mathrm{k}}=$ fixed effect of $\mathrm{k}^{\text {th }}$ Stage of lactation $(\mathrm{k}=$ early, mid and late)

$\mathrm{T}_{1}=$ fixed effect of $1^{\text {th }}$ time of milking (l=morning and evening)

$\mathrm{e}_{\mathrm{iklmnopq}}=$ random residual error

\section{Results and discussion}

\section{Milk yield of Red Sokoto and Boer goats}

The estimated milk yield of Red Sokoto and Boer goats is presented in Table 1 . Significant difference $(p<0.05)$ was observed in the total morning milk yield between the goats. The total morning milk yield was higher $(2642.00 \pm 3.18 \mathrm{~g})$ in the Boer goats than in the Red Sokoto (2371.50 $\pm 3.18 \mathrm{~g}$ ). However, the average daily milk yield, total milk yield and total evening milk yield were not significantly $(p>0.05)$ affected by the breeds of goat. The higher milk yield obtained for the morning hours milking could be attributed to the period of rest experienced by the animals. Fajeminsin (1991) reported $728 \mathrm{~g}$ of milk yield for twice a day milking which is higher than $522 \mathrm{~g}$ for once a day milking in Red Sokoto goats. Akpa, Osuhor, Olugbemi and Nwani (2003) observed that twice a day milking appears to be the optimum milking interval in Red Sokoto goats because it increased milk yield by $52.7 \%$. The milk yields of the two breeds in the present study are higher than $118 \pm 1.12 \mathrm{~mL}$ for RS does reported by James and Osinowo (2004). The present study reported higher mean daily milk yield than the findings of Makun et al. (2008) who observed $135.9 \mathrm{~mL}$ and $134.7 \mathrm{~mL}$ for Red Sokoto and Sahelian goats respectively. Moreover, the milk yield of 0.14 L per day of Red Sokoto as reported by Makun, Otaru and Dung (2013)(Makun et al., 2013) is lower than the current observation. James, Osinowo, Smith, Bemji and Rekwot (2009) recorded daily milk yield of $149.29 \mathrm{ml}$ for West African Dwarf goats. The findings of Luka and Kibon (2014) for Red Sokoto goat (100 g per day) is also lower than this study. However, Akpa (1999) and Akpa et al. (2003) reported average daily milk yield of $466.9 \mathrm{~g}$ and 664 $\mathrm{g}$ for Red Sokoto goats respectively which are higher than the average value obtained in the present study. Also, the milk yield currently reported was lower than $188.27 \pm 1.28 \mathrm{~mL}$ for Red Sokoto (Zahraddeen et al., 2009). Ahamefule et al. (2012) reported lower average milk yield for Red Sokoto (132.5 g/day) and West African Dwarf goats (92.5 g/day) than the current findings. Milk yield from the Boer breed in the present findings is lower than different values reported by many authors as Casey and Van Nierkerk (1988) obtained $1.5-2.5 \mathrm{~kg} / \mathrm{d}$. Greyling et al. (2004) reported under intensive management obtained $3.1 \mathrm{~kg} /$ day of milk. Ciappesoni et al. (2004) recorded daily milk yield of $3.09 \mathrm{~kg}$ /day for Czech White Shorthaired breed of goats. 


\section{Muhammad, Garba, Ogah and Inusa}

Mioc et al. (2008) observed from their research in Croatia average daily milk yield of $2.08 \pm 0.01 \mathrm{~kg}$ and $2.63 \pm 0.04 \mathrm{~kg}$ for Alpine and Saanen goat breeds respectively. Mestawet et al. (2012) reported $1.41 \mathrm{~kg} / \mathrm{d}$ for Boer. Idamokoro et al. (2017) reported $1.0 \mathrm{~L} /$ day and reported Boer milk yield of $1.72 \mathrm{~kg} /$ day. The short fall in milk yield of the Red Sokoto and Boer goat breeds might be as result of the non-adaptability of the breeds to the new environment that differs from their indigenous habitat or because they were in their first parity as Zahradeen et al. (2009) opined that milk yield is significantly influenced by parity, breed, body condition score, season and litter size. The authors further stated that milk yield increased progressively with advance in parity. This confirms the observations made by Butswat et al. (2002) that the milk yield of Red Sokoto goat increased significantly up to the third parity and declined subsequently. Peris et al. (1997) reported that first parity order goats had the lowest milk yield but highest milk fat and protein percentages and the third parity goats had highest milk yield. According to Basic, Dzidic and Kostelic (2009), variation in milk yield of goats could be due to differences in parity. Furthermore, the low milk yield of the indigenous RS and exotic Boer genotypes could be due to the fact that the goats are traditionally used for meat and not for dairy purpose. Also, Zahradeen (2006) stated that goats with twins had more milk yield compared to those with single kids which could probably be associated with extra pressure on the udder due to the increased stimulation. The experimental animals in this study had single kids. Morand-Fehr et al. (2007) attributed the variations in milk yield of various goats in different local environments to factors including genetic, environmental and management practices.

Table 1: Milk Yield of Red Sokoto and Boer goats

\begin{tabular}{lllll}
\hline & & Milk Yield (g) & & \\
\hline Breed & ADMY & TMY & TMMY & TEMY \\
\hline Red Sokoto & $159.06 \pm 0.66$ & $3817.50 \pm 15.91$ & $2371.50^{\mathrm{b}} \pm 3.18$ & $1446.00 \pm 12.72$ \\
Boer & $170.29 \pm 0.66$ & $4087.00 \pm 15.91$ & $2642.00^{\mathrm{a}} \pm 3.18$ & $1445.00 \pm 12.72$ \\
P-Value & 0.0530 & 0.0530 & $0.0106^{*}$ & 0.9647 \\
\hline
\end{tabular}

$\mathrm{a}, \mathrm{b}, \mathrm{c}$ : means with different superscripts on the same column are significantly $(\mathrm{p}<0.01)$ different.

Least Square Mean \pm Standard Error, ADMY; Average Daily Milk Yield, TMY; Total

Milk Yield, TMMY; Total Morning Milk Yield, TEMY; Total Evening Milk Yield

Effect of stage of lactation and time of milking on mean milk yield (g) of Red Sokoto and Boer goats

The results on the effect of stage of lactation and time of milking on mean milk yield ( $\mathrm{g}$ ) of Red Sokoto and Boer goats are shown in Table 2. Mean milk yield was significantly $(\mathrm{P}<0.05)$ influenced by stage of lactation and time of milking. The milk yield was significantly higher $(98.91 \mathrm{~g})$ in the late lactation while the least was obtained in the mid stage of lactation (65.44 g). However, the morning milk yield was significantly higher than the evening milk yield. A significant interaction effect $(p<0.05)$ of lactation stage and milking time was similarly observed. The finding of this study revealed that mean milk yield was influenced by the stage of lactation and time of milking. The morning milk yield was higher than the evening milk yield among the experimental goat breeds. Similar results on the higher morning milk than evening milk yield were also observed by Katanos et al, (2005), Quist et al. (2008). The mean milk yield of Red Sokoto and Boer goats was highest in the late stage followed by early stage and lowest in the mid stage of lactation. Mioc et al. (2008) stated that in Croatia the Alpine and Saanen 
goat breeds had milk yields for early, middle and late lactations as $2.50 \pm 0.01,2.24 \pm 0.01$ and $1.86 \pm 0.02 \mathrm{~kg}$ respectively which are higher than the present study. Mahmoud et al. (2014) reported milk yield of first parity goats at early, middle and late lactation stages as $1.34 \mathrm{~L}, 1.24 \mathrm{~L}$ and $0.96 \mathrm{~L}$, respectively.

Table 2: Effect of stage of lactation and time of milking on mean milk yield (g) of Red Sokoto and Boer goats

\begin{tabular}{lc}
\hline Stage of Lactation & Milk yield $(\mathbf{g})$ \\
\hline Early & $90.42^{\mathrm{b}}$ \\
Mid & $65.44^{\mathrm{c}}$ \\
Late & $98.91^{\mathrm{a}}$ \\
SE \pm & 9.471 \\
P-value & 0.0306 \\
Time of milking & \\
Morning & $103.05^{\mathrm{a}}$ \\
Evening & $66.80^{\mathrm{b}}$ \\
SE \pm & 8.008 \\
P-value & 0.0017 \\
Stage of Lactation X Time & \\
SE \pm & 13.388 \\
P-value & 0.0451 \\
\hline
\end{tabular}

a,b,c: means with different superscripts on the same column are significantly $(\mathrm{p}<0.01)$ different.

$\mathrm{SE} \pm$ Standard Error; P-value = probability level

Udder traits of Red Sokoto and Boer goat breeds

The udder traits of Red Sokoto and Boer goat breeds considered in this study are presented in Table 3. The results indicated that breed significantly $(p<0.05)$ influenced most of the udder characteristics except UC, UW and TFD. Significantly $(p<0.05)$ higher values of UL, UW, TC, RTL, LTL, $\mathrm{CH}$ and TFD in the Red Sokoto. Furthermore, the Boer goat breed had significantly higher values of UC and DBT. James (2000) reported that udder size could be a good determinant for milk production potential in goats. Milk yield is also largely affected by the population of cells in the mammary gland (Dijkstra et al., 1997). Akpa et al. (1998) also suggested that udder traits and their high heritability values could be possible selection markers for milk improvement in goats. The present study recorded higher values of TL $(2.90 \mathrm{~cm})$, teat height to ground $(22.14 \mathrm{~cm})$ and TC (3.34 $\mathrm{cm})$ compared to the values obtained by Zahradeen et al. (2007) for Red Sokoto obtained lower values of UL $(14.13 \mathrm{~cm})$ and UC $(30.03 \mathrm{~cm})$. The values for UL, UW and UC obtained in the present study are higher than those reported by James et al. (2009) for WAD goat (UL, $9.61 \mathrm{~cm}$; UW, $7.62 \mathrm{~cm}$ and UC, $24.60 \mathrm{~cm})$. The udder measurements obtained by Kouri, Charallah, Kouri, Amirat and Khammar (2019) are higher than the values obtained in the present study. Merkhan and Alkass (2011) reported lower mean values of UL, UW and a higher value of UC $(36.65 \pm 1.30)$ in Meriz and Black goats compared to those in the present study but similar teat lengths. 
Table 3: Udder traits of Red Sokoto and Boer goat breeds

\begin{tabular}{llllllllll}
\hline \multicolumn{7}{c}{ Udder Traits } \\
\hline Breed & UL(cm) & UC(cm) & UW $(\mathbf{c m})$ & TC(cm) & RTL(cm) & LTL(cm) & DBT(cm) & CH $(\mathbf{c m})$ & TFD(cm) \\
\hline Red Sokoto & $12.59^{\mathrm{a}}$ & 25.18 & 13.92 & $4.28^{\mathrm{a}}$ & $3.71^{\mathrm{a}}$ & $3.93^{\mathrm{a}}$ & $7.54^{\mathrm{b}}$ & $13.94^{\mathrm{a}}$ & 27.91 \\
Boer & $11.25^{\mathrm{b}}$ & 25.76 & 12.81 & $2.51^{\mathrm{b}}$ & $2.38^{\mathrm{b}}$ & $1.97^{\mathrm{b}}$ & $9.41^{\mathrm{a}}$ & $8.15^{\mathrm{b}}$ & 26.70 \\
SE \pm & 0.361 & 0.930 & 0.662 & 0.500 & 0.308 & 0.375 & 0.526 & 0.857 & 0.517 \\
P-value & 0.0176 & 0.6700 & 0.2588 & 0.0227 & 0.0073 & 0.0017 & 0.0230 & 0.0002 & 0.1198 \\
\hline
\end{tabular}

$\mathrm{a}, \mathrm{b}$ : means with different superscripts on the same column are significantly $(\mathrm{p}<0.01)$ different, $(\mathrm{p}<0.05)$

$\mathrm{SE} \pm=$ Standard Error , p-value; probability value, UL; Udder length, UC; Udder

circumference, UW; Udder width, TC; Teat circumference, RTL; Right Teat length, LTL; Left teat length

DBT; Distance between teats CH; Cistern height, TFD; Teat floor distance

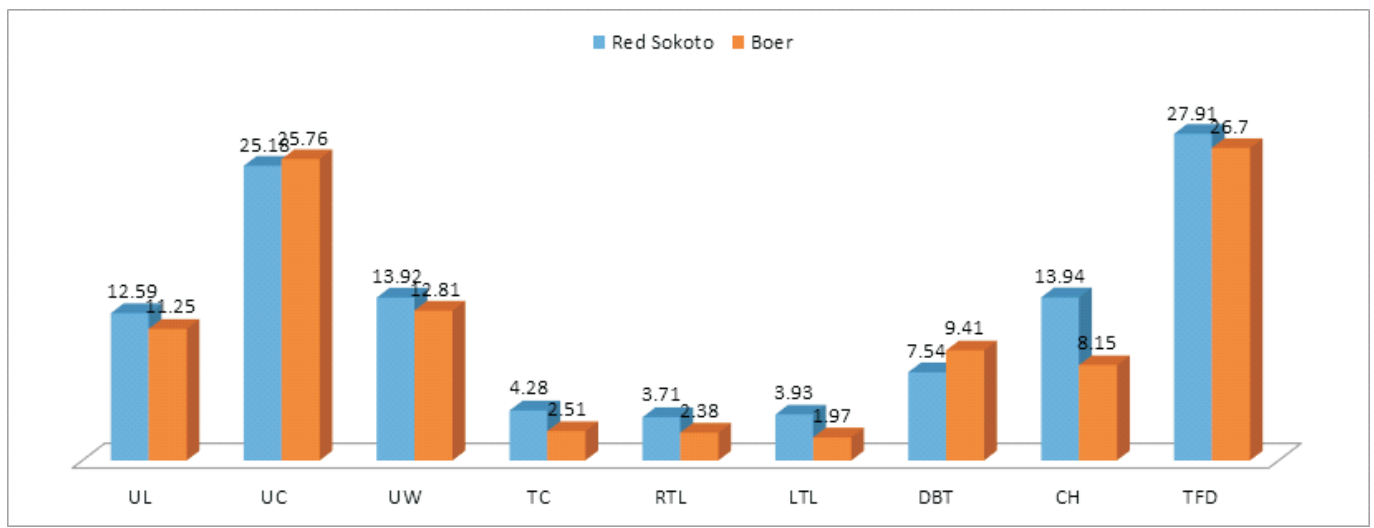

\section{Figure 2: Udder traits of Red Sokoto and Boer goat breeds}

\section{Conclusion}

The result of the study has showed that higher milk yields were obtained in the Boer breed than in the Red Sokoto. It is suggested that milking of the animals should target the morning hours and should be done twice daily in order to obtain more yields. Direct method of milking should also be employed so as obtain the actual amount of milk yield by the does. It is therefore recommended that the study should be replicated on a larger scale in order to increase its precision which will aid researchers, breeders and farmers in management decisions, selection and sustainable breeding programmes.

\section{References}

Abdel Aziz, M. 2010. Present status of the world goat populations and their productivity. Lohman Information, 45(2): 42-52.
African Union-InterAfrican Bureau for Animal Resources (AU-IBAR), 2020. The Red Maradi (Capra hircus). Retrieved on 15/12/2020 f $\quad r \quad 0 \quad m$ : http://20151001_kya_chevre_rouss e october 2015 en.pdf

Ahamefule, F. O., Odilinye, O. and Nwachukwu, E. N. 2012. Milk Yield and Composition of Red Sokoto and West African Dwarf Does Raised Intensively in a Hot Humid Environment. Iranian Journal of Applied Animal Science, 2(2): 143-149

Akpa G. N., Osuhor C. U., Olugbemi T. S. and Nwani P. I. 2003. Milk flow rate and milking frequency in Red Sokoto goats. Pakistan Journal of Nutrition, 2(3): 192-195.

Akpa, G. N. 1999. Evaluation of dairy characteristics and lactation curves 
of small holder Red Sokoto (Maradi) goats. Ph.D. Thesis. Ahmadu Bello University, Zaria, Nigeria.

Akpa, G. N., Asiribo, O. E., Oni, O. O., Alawa, J. P., Dim, N. I. and Osinowo, O. A. 2002. Milk production by agro pastoral Red Sokoto goats in Nigeria. Tropical Animal Health and Production. 34:525-533.

Akpa, G. N., Duru, S., Dim, N. I., Alawa, J. P. and Jokthan, G. E. 1998, March. Sources of variation in udder traits of Red Sokoto goats. Proceedings of Silver Anniversary Conference of Nigerian Society of Animal Production, Abeokuta, Nigeria, March, 21-26.

Assan, N. 2014. Effect of breed, stage of lactation and nutrition on milk production traits in goats. Scientific Journal of Review, 3(12): 985-992.

Basic, Z., Dzidic, A. and Kostelic, A. 2009. The effect of pre stimulation on milking characteristics during machine milking of goat. Mljekarstvo, 59, 83-87.

Butswat, I. S. R., Zahradeen, D., Mancha, Y. P. and Dachollom, C.C. 2002, September. Effects of breeds and parity on milk yield of Red Sokoto and Sahel goats. Proceedings of the 7th annual conference of Animal Science Association of Nigeria September 16-19, University of Agriculture, Abeaokuta, Nigeria. Pp17-21.

Campbell, Q. P. 1984. The development of a meat-producing goat in South Africa. Proceedings of the 2nd Congress on Sheep and Beef Cattle Breeding, Republic of South Africa.

Campbell, Q. P. 2003. The origin and description of southern Africa's indigenous goats. South African Journal of Animal Science. $33: 18-22$.
Casey, N. H. and Van Niekerk, W. A. 1988. The Boer goat 1. Origin, adaptability, performance testing, reproduction and milk production. Small Ruminant Research. 1: 291302.

Ciappesoni, G., Pribyl, J., Milerski, M. and Mares, V. 2004. Factors affecting goat milk yield and its composition. Czech Journal of Animal Sciences 49(11): 465-473.

Devendra, C. 2000. Animal production and rain-fed agriculture in Asia: Potential opportunities for productivity enhancement. Outlook Agriculture, 29:161-175.

Dijkstra, J., France, J., Dhanoe, M.S., Maas, J. A. and Hanigan, M. D. 1997. A Model to Describe Growth Patterns of the Mammary Gland during Pregnancy and Lactation. Journal of Dairy Science. 80: 23402354.

Fajeminsin, B. A. 1991. Goat milk production, In: National Animal Production Research Institute Proceedings of Seminar, pp: 1-13).

$\begin{array}{lllllllllll}\text { F A O S } & \text { T A T T } & 2 & 0 & 0 & 8\end{array}$. http://faostat.fao.org/default.aspx. (Retrieved 2/7/2017).

$\begin{array}{lllllllllll}\text { F A O S T A T } & \text { T } & 0 & 1 & 8\end{array}$ http://www.fao.org/faostat/en/\#data /QA. (Retrieved 15/12/2020)Food and Agriculture Organization of the United Nations, FAO, 2019 [cited 2019 Feb 16]. Statistical Databases. Available from: http:// faostat.fao.org/

Goonewardene, L. A., Okinea, E., Patrick, N. and Scheer, H. D. 1999. The relationship between multiple births and milk yields in nonsuckled intensively managed dairy goats. Small Ruminant Research, 32: 181-185.

Greyling, J. P., Mmbengwa, V. M., Schwalbach, L. M. J. and Muller, 
T. 2004. Comparative milk production potential of indigenous and Boer goats under two feeding systems in South Africa. Small Ruminant Research, 55 (1-3): 97105.

Hatziminaoglou, Y. and Boyazoglu, J. 2004. The goat in ancient civilizations: from the Fertile Crescent to the Aegean Sea. Small Ruminant Research, 51:123-129.

Ibrahim, M. T. 2000. Studies on some productive and reproductive parameters of Nubian Goats and their Saanen crossbreds under local environmental conditions. PhD. Thesis, University of Khartoum, 1:25-33.

Idamokoro, E. M., Muchenje, $\mathrm{V}$ and Masika, P. J. 2017. Yield and Milk Composition at Different Stages of Lactation from a Small Herd of Nguni, Boer, and Non-Descript Goats Raised in an Extensive Production System. Sustainability (9) $1000,13 p$

James, I. J. 2000. Changes in udder traits of West African Dwarf, Red Sokoto and Sahel goats during pregnancy and lactation and their effects on partial daily milk yield. M. Agric. Thesis. University of Agriculture. Abeokuta. Nigeria. 98 pp.

James, I. J and Osinowo, A. O. 2004. Changes in udder size and liveweight of West African Dwarf, Red Sokoto and Sahel goats during lactation and their phenotypic relationships with partial daily milk yield. Nigerian Journal of Animal Production 31: 119-129.

James, I. J., Osinowo, O. A. Smith, O. F. Bemji, M. N and Rekwot, P. I. 2009. Effects of Bovine Somatotropin on changes in udder dimensions after cessation of milking in West African Dwarf
Goats. Journal of agricultural Science and Environment 9(2):7078

Katanos, J., Skapetas, B and Laga, V. 2005. Machine Milking Ability and Milk Composition of some imported Dairy Goat Breeds and some Crosses in Greece. Czech Journal of Animal Science, 50(9): 394-401.

Kouri, F., Charallah, S., Kouri, A., Amirat, Z and Khammar, F. 2019. Milk production and its relationship with milk composition, body and udder morphological traits in Bedouin goat reared under arid conditions. Acta Scientiarum, 41. d 0 i : 10.4025/actascianimsci.v41i1.4255 2

Lu, C. D. 2001, October. Boer goat production: Progress and perspective. Proceedings of the 2001 International Conference on Boer Goats in China, October 21-24, 2001, Guizhou, China.

Lu, C. D and Miller, B. A. 2019. Current status of global dairy goat production: an overview. AsianAustralasian Journal of Animal Science. 32 (8):1219-1232. https://doi.org/10.5713/ajas.19.025 3

Luka, J. S and Kibon, A. 2012. Milk Production of Red Sokoto Goats Fed with Supplements in Bauchi State, Nigeria. Discourse Journal of Agriculture and Food Sciences, 2(8): 258-263.

Mahmoud, N. M. A., El Zubeir, I. E. M and Fadlelmoula, A. A. 2014. Effect of stage of lactation on milk yield and composition of first kidder Damascus does in the Sudan. Journal of Animal Production Advances, 4: 355-362.

Makun, H. J., Ajanusi, J. O., Ehoche, O. W., Lakpini, C. A. M and Otaru, S. 
M. 2008. Growth rates and milk production potential of Sahelian and Red Sokoto breeds of goats in northern Guinea Savannah. Pakistan Journal of Biological Sciences 11(40):601-606. https://doi.org/10.3923/pjbs.2008.6 01.606

Makun, H., Otaru, S and Dung, D. 2013. Effect of management practices on milk yield and live weight changes of indigenous breeds of goats supplemented with groundnut haulms and concentrate in sub humid zone of Nigeria. Sokoto Journal of Veterinary Sciences, 11(1): 45-50. https://doi.org/ 10.4314/sokjvs.v11i1.7

Makun, H. J., Ajanusi, J. O., Ehoche, O. W., Olorunju, S. A. S and Otaru, S. M. 2005. Ownership Patterns of goats and goat Milking Practices in Nigeria, Ahmadu Bello University, Savanna, 20(1): 17-29.

Malau-Aduli, B. S., Eduvie, I. O., Lakpini, C. A. M and MalauAduli, A. E. O. 2001, March. Effect of supplementation on the milk yield of Red Sokoto does. Proceedings of the 26th annual Conference of Nigerian Society of Animal Production, March 2001 ABU, Zaria, Nigeria, pp 353-355.

Merkhan, K. Y and Alkass, J. E. 2011. Influence of udder and teat size on milk yield in Black and Meriz goats. Research Opinions in Animal \& Veterinary Sciences, 1(9): 601-605.

Mioč, B., Prpić, Z., Vnučec, I., Barać, Z., Sušić, V., Samaržija, D and Pavić, V. 2008. Factors affecting goat milk yield and composition. Mljekarstvo, $58(4): \quad 305-313$. https://doi.org/10.17221/4333-cjas

Morand-Fehr, P., Fedele, V., Decandia, M and Le Frileux Y. 2007. Influence of farming and feeding systems on composition and quality of goat and sheep milk. Small Ruminant Research, 68(1-2):20-34. https://doi.org/10.1016/j.small rumres.2006.09.019.

Negesse, T., Rodehutscord, $M$ and Pfeffer, E. 2001. The effect of dietary crude protein level on intake, growth, protein retention and utilization of growing male Saanen kids. Small Ruminant Research, 39: 243-251.

Nigerian Meteorological Agency, 2014. $\mathrm{R}$ e $\mathrm{t} \mathrm{r}$ i e $\mathrm{ved}$ f $\mathrm{r}$ o m http://www.nimet.gov.ng/publicatio n/seasonal-rainfall-prediction-2014

Otoikhian, C. S. O and Orheruata, A. M. 2010. White Bornu goats: Untapped meat breed in Nigerian small ruminant industry. Klobex Academic Publishers. Bioscience Research Communications, 22: 6.

Papachristoforou, $\mathrm{C}$ and Mavrogenis, $\mathrm{A}$. P. 1981. Udder characteristics of Chios sheep and their relation tomilk production and machine milking. Agricultural Research Institute., Cyprus, Technical Paper, 20:9 ISSN, 0379-0932.

Park, Y. W and Haenlein, G. F. W. 2006. Handbook of Milk of Non-Bovine Mammals. Blackwell Publishing, Ames, Iowa, USA/Oxford, UK, 449 pp.

Peris, S., Caja, G., Such, X., Casals, R., Ferret, A and Torre, C. 1997. Influence of kid rearing systems on milk composition and yield of Murciano-Granadina dairy goats. Journal of Dairy Science, 80: 32493255.

Quist, M. A., Blanc, S. J., Hand, K. J., Lazenby, D., Miglior, $F$ and Kelton, D. F. 2008. Milking to milking variability for milk yield, fat and protein percentage, and somatic cell count. Journal of Dairy Science, 
91(9): 3412-3423.

SAS, 2018. SAS Institute Inc. 2018. Discovering JMP 14®. Cary, NC: SAS Institute Inc.

Shaat, I., Mabrouk, M., Raheem, A. A and Hamed, A. 2009. Estimates of heritability and correlation for milk and growth traits in Zaraibi goat. Egyptian Journal of Animal Production, 44(2), 161-171. doi: 10.21608/ejap.2007.93161

Silanikove, N. 2000. The physiological basis of adaptation in goats to harsh environments. Small Ruminant Research, 35: 181-193.

Zahraddeen, D. 2006. Studies on reproductive performance and milk productivity of goats in Bauchi. Ph.D. Thesis, Abubakar Tafawa Balewa University, Bauchi, Nigeria, 210pp.
Zahraddeen, D., Butswat, I. S. R and Mbap, S. T. 2009. A note on factors influencing milk yield of local goats under semi-intensive system in Sudan savannah ecological zone of Nigeria. Livestock Research for Rural Development, 21(3):

Zahraddeen, D., Butswat, I. S. R and S. T. Mbap. 2007. Evaluation of some factors affecting milk composition of indigenous goats in Nigeria. Livestock Research for Rural Developement. 19(11).

Zapasnikienè, B. 2015. Kaip auginti ožką. Baisogala: Liucijus. 60p

Received: $30^{\text {th }}$ April, 2021 Accepted: $16^{\text {th }}$ August, 2021 